\title{
Designing Social Worlds - On Intrigue and Interaction in Live Action Role Playing Games (LARPS)
}

\author{
Carl Heath \\ GR Experiential Learning, Sweden \\ Carl.Heath@grkom.se
}

\begin{abstract}
The past 20 years have seen Live Action Role Playing evolve to become a complex scene of games in the Nordic countries. The Nordic LARP scene has been a creative, dynamic and experimental environment where questions regarding the design of intrigue and interaction have been explored from many perspectives. Over the past years the knowledge within this subcultural context has spread into several academic fields, into the schools of the nordic countries, to the national theatre stages, into other types of games and also into mainstream media. During this keynote Carl Heath will take us on a journey into this subculture, on an exploratory path aiming to explain key elements in the design of the rich and complex social worlds that can be found within LARPs in the Nordic countries.
\end{abstract}

\section{Biography}

Carl Heath is the Creative Director of GR Experiential Learning, a part of the Gothenburg Region. He has designed Live Action Role Playing games since the early 90 s in genres ranging from fantasy and science fiction to historical to modernistic drama. Among the works produced, of special note is the LARP version of Hamlet, produced in 1999 together with the Swedish National Theatre and the game OB7 in 2003 delving deep into the depths of Swedish cold war politics. Since 2003 Carl Heath works at the Gothenburg Region, where he has lead a team designing educational LARPs and games in general, the last one being an interactive narrative drama within the field of Human Rights Education. During these years he has produced a number of games for organisations such as the Swedish National Parliament, The European Parliament, The European Commission, The Council of Nordic Ministers, as well as several municipal and regional organisations in Sweden. 